\title{
Quantifying potential benefits of drought and heat tolerance in rainy season sorghum for adapting to climate change
}

\author{
Piara Singh $^{\mathrm{a}, *}$, S. Nedumaran ${ }^{\mathrm{a}}$, P.C.S. Traore ${ }^{\mathrm{b}}$, K.J. Boote ${ }^{\mathrm{c}}$, H.F.W. Rattunde $^{\mathrm{b}}$, \\ P.V. Vara Prasad ${ }^{d}$, N.P. Singh ${ }^{a}$, K. Srinivas ${ }^{a}$, M.C.S. Bantilan ${ }^{a}$ \\ a International Crops Research Institute for the Semi-Arid Tropics (ICRISAT), Patancheru 502 324, Andhra Pradesh, India \\ ${ }^{\mathrm{b}}$ International Crops Research Institute for the Semi-Arid Tropics (ICRISAT), Bamako BP 320, Mali \\ c Agronomy Department, University of Florida, IFAS, Gainesville, FL 32611-0500, USA \\ d Agronomy Department, 2004 Throckmorton Hall, Kansas State University, Manhattan, KS 66506-5501, USA
}

\section{A R T I C L E I N F O}

\section{Article history:}

Received 18 April 2013

Received in revised form 16 October 2013

Accepted 29 October 2013

\section{Keywords:}

Genetic adaptation

Plant traits

Crop modeling

Sorghum model

Climate change factors

\begin{abstract}
A B S T R A C T
Maintaining high levels of productivity under climate change will require developing cultivars that are able to perform under varying drought and heat stresses and with maturities that match water availability. The CSM-CERES-Sorghum model was used to quantify the potential benefits of altering crop life cycle, enhancing yield potential traits, and incorporating drought and heat tolerance in the commonly grown cultivar types at two sites each in India (cv. CSV 15 at both Akola and Indore) and Mali (cv. CSM 335 at Samanko and cv. CSM 63E at Cinzana), West Africa. Under current climate CSV 15 on average matured in 108 days and produced $3790 \mathrm{~kg} \mathrm{ha}^{-1}$ grain yield at Akola; whereas at Indore it matured in 115 days and produced $3540 \mathrm{~kg} \mathrm{ha}^{-1}$ grain yield. Similarly under current climate, CSM 335 matured in 120 days and produced $2700 \mathrm{~kg} \mathrm{ha}^{-1}$ grain yield at Samanko; whereas CSM 63E matured in 85 days at Cinzana and produced $2210 \mathrm{~kg} \mathrm{ha}^{-1}$ grain yield. Decreasing crop life cycle duration of cultivars by $10 \%$ decreased yields at all the sites under both current and future climates. In contrast, increasing crop life cycle by $10 \%$ increased yields up to $12 \%$ at Akola, $9 \%$ at Indore, $8 \%$ at Samanko and 33\% at Cinzana. Enhancing yield potential traits (radiation use efficiency, relative leaf size and partitioning of assimilates to the panicle each increased by $10 \%$ ) in the longer cycle cultivars increased the yields by $11-18 \%$ at Akola, 17-19\% at Indore, $10-12 \%$ at Samanko and $14-25 \%$ at Cinzana under current and future climates of the sites. Except for the Samanko site, yield gains were larger by incorporating drought tolerance than heat tolerance under the current climate. However, under future climates yield gains were higher by incorporating heat tolerance at Akola, Samanko and Cinzana, but not at Indore. Net benefits of incorporating both drought and heat tolerance increased yield up to $17 \%$ at Akola, 9\% at Indore, $7 \%$ at Samanko and 16\% at Cinzana under climate change. It is concluded that different combinations of traits will be needed to increase and sustain productivity of sorghum in current and future climates at these target sites and that the CSM-CERES-Sorghum model can be used to quantify benefits of incorporating certain traits.
\end{abstract}

(c) 2013 Elsevier B.V. All rights reserved.

\section{Introduction}

Sorghum (Sorghum bicolor L.) is an important staple food for many poor people and a source of feed and fodder for livestock production in India and sub-Saharan Africa. In India, it is grown on $8.02 \mathrm{M}$ ha with an average productivity of $920 \mathrm{~kg} \mathrm{ha}^{-1}$. In West Africa, Nigeria is the largest producer of sorghum followed by Burkina Faso and Mali. In Mali, it is grown on $1.06 \mathrm{M}$ ha with an average productivity of $1020 \mathrm{~kg} \mathrm{ha}^{-1}$ (mean of 2006-2010 production data, FAO, 2012). Climate change, in terms of higher

\footnotetext{
* Corresponding author. Tel.: +91 04030713334 ; fax: +91 $04030713074 / 30713075$.

E-mail addresses: p.singh@cgiar.org, piarasingh48@gmail.com (P. Singh).
}

temperatures, changing precipitation patterns and increased frequency of extreme weather events (IPCC, 2007), will alter the current crop growing conditions across the globe with crop yields affected either negatively or positively. However, in the most arid and semiarid tropical regions, the projected climate change effect will be mostly negative thus threatening food security in these regions (Fischer et al., 2005; Howden et al., 2007). In the semiarid tropical regions the changes in rainfall coupled with a rise in temperature may reduce the length of the growing period (LGP) as determined by the duration of soil water availability (Cooper et al., 2009). Therefore, it will be important that the maturities of crops match the periods of water availability to achieve higher and stable yields. The optimum air temperature range for vegetative and reproductive growth of sorghum is $26-34^{\circ} \mathrm{C}$ (Hammer et al., 1993; Alagarswamy and Ritchie, 1991) and $25-28^{\circ} \mathrm{C}$ (Prasad et al., 
2006, 2008), respectively. In the semi-arid tropics where sorghum is currently grown during the rainy season, the mean crop-season temperatures are already close to or above these optimum temperatures. However, increased $\mathrm{CO}_{2}$ concentration in the atmosphere could have beneficial effects on crop growth, and could partially negate the detrimental effects of rising temperatures depending on the degree of the temperature rise, and the extent of crop transpiration reductions under elevated $\mathrm{CO}_{2}$. Srivastava et al. (2010), using the InfoCrop-Sorghum simulation model and the HadCM3 output for the A2a scenario, projected that climate change in different regions of India will reduce the rainy season sorghum yield by $3-16 \%$ by 2020 and $17-76 \%$ by $2050-2080$; whereas for the postrainy season sorghum, climate change would likely reduce yields up to $7 \%$ by $2020,11 \%$ by 2050 and $32 \%$ by 2080 . Blane (2012) used a panel data approach to relate crop yields to standard weather variables and estimated 7-47\% reduction in yield of sorghum for sub-Saharan Africa by 2100 . Using the EPIC crop model and the HadCM climate model output, Butt et al. (2005) predicted an $11-17 \%$ reduction in sorghum yield for Mali by 2030 . Other simulation studies for Africa (Tingem et al., 2008, 2009; Chipanshi et al., 2003) also reported substantial reductions in sorghum yield under future climates.

When climate changes are relatively small, the current agronomic adaptation measures can help farmers adapt. However, more extensive changes may require genetic improvement of crops for greater tolerance to elevated temperatures and drought, improved responsiveness to rising $\mathrm{CO}_{2}$ and the development of new agronomic technologies (Boote et al., 2011). Because agriculture will not experience the same climate change in all regions, site-specific improved crop varieties, cropping systems and management practices will be needed to adapt to the characteristics of the future climates and other natural endowments of each region. Plant breeders are already targeting specific plant traits to breed new crop varieties that will perform better in future climates (Reddy et al., 2011; Nguyen et al., 2013). Therefore, an early assessment of the potential benefits of such traits in the target environments is needed before significant investments are made to pursue these goals. Plant growth simulation models can be used to assess crop growth and yield advantages due to new technologies in different environments by using environment-specific weather, soil and agronomic management data (Boote et al., 2001). Since these crop models incorporate parameters representing genetic traits, they can be used to predict the potential benefit single or multiple combinations of traits would have on crop performance in a target environment (Boote et al., 2001; Singh et al., 2012). Using crop models, many researchers in the past have proposed plant ideotypes or genetic improvement of crops for higher yields (Landivar et al., 1983; Boote and Tollenaar, 1994; Yin et al., 1999; Hammer et al., 1996, 2002, 2005, 2010; Tardieu, 2003; White and Hoogenboom, 2003; Messina et al., 2006; Suriharn et al., 2011). Hammer et al. (2005, 2010) used the ASPIM modeling framework to hypothesize genetic improvement in sorghum, although they did not focus on issues of adaptation to climate change. Under climate change new constraints and opportunities for crop production are emerging, thus these studies need to be further extended to determine new plant types for improved adaptation to future climates of the target regions. With improved knowledge, understanding and modeling of crop response to climate change factors (high temperatures, increased rainfall variability, increased atmospheric $\mathrm{CO}_{2}$ concentration and their interactions); crop models have excellent potential to assess benefits of genetic improvement for higher yields and adaptation to current and future target environments. The objective of this study was to quantify the potential benefits of genetic improvement, particularly crop life cycle, yield potential, drought and heat tolerance traits and their combinations, on sorghum yields under current and future climates of selected sites in the sorghum growing areas of India and West Africa.

\section{Materials and methods}

Simulations of sorghum were carried out for two sites each in India (Akola and Indore) and Mali (Samanko and Cinzana), West Africa. The geographical, soil and climatic characteristics of the sites are given in Table 1.

\subsection{The sorghum model and input data}

We used the CSM-CERES-Sorghum model, which is a part of the DSSAT v4.5 (Decision Support System for Agro-technology Transfer, version 4.5) (Hoogenboom et al., 2010), to study the impact of climate change factors and genetic modifications on the productivity of sorghum. The major components of the sorghum model are vegetative and reproductive development, carbon, water and nitrogen balance and these processes have been described in detail by Ritchie et al. (1998) and Ritchie (1998). The model simulates sorghum growth and development using a daily time step from sowing to maturity and ultimately predicts yield. The model is sensitive to various climate change factors such as high temperature, variability in rainfall and increased $\mathrm{CO}_{2}$ concentrations in the atmosphere. In the model, high temperature influences growth and development by shortening the crop life cycle and reducing allocation of biomass to the reproductive organs through decreased seed set and seed growth rate. Increased $\mathrm{CO}_{2}$ concentration in the atmosphere increases crop growth and biomass production through increased radiation use efficiency (RUE). Increased $\mathrm{CO}_{2}$ also reduces transpiration from the crop canopy via an empirical relationship between canopy conductance and $\mathrm{CO}_{2}$ concentration. These two processes of $\mathrm{CO}_{2}$ effects are described in detail in Sections A. 1 and A.2 of Appendix A. Changes in rainfall characteristics influence soil water balance and thus the pattern of water availability to the crop during its life cycle. Thus the model has the potential to simulate the impact of climate change on growth and development of sorghum.

The minimum data set required to simulate a crop is described by Jones et al. (2003). Briefly, it includes site characteristics (latitude and elevation), daily weather data (solar radiation, maximum and minimum air temperatures and precipitation), basic soil profile characteristics by layer (soil saturation limit, drained upper limit and lower limit of water availability, bulk density, organic carbon, $\mathrm{pH}$, root distribution factor, runoff and drainage coefficients) and management data (cultivar, sowing date, plant population, row spacing, sowing depth, dates and amounts of irrigation and fertilizers applied). The cultivar data include the genetic coefficients (quantified traits) that distinguish one cultivar from another in terms of phenological development, photoperiod sensitivity, growth and partitioning to vegetative and reproductive organs. Crop-specific parameters, which describe the basic processes of crop growth, development and yield formation of sorghum, are also inputs to the model.

For India, the soil profile data for the sites were obtained from the soil survey bulletins published by the National Bureau of Soil Survey and Land Use Planning, Nagpur, India (Lal et al., 1994). Long-term weather data (daily records of rainfall, maximum and minimum temperatures) for the sites were obtained from the India Meteorology Department, Pune, India. Solar radiation for the sites was estimated from the temperature data following the method of Bristow and Campbell (1984). For the Samanko and Cinzana sites, the soils data were taken from the records of the ICRISAT Research Station at Bamako, Mali. The weather data for the Samanko and Cinzana sites were downloaded from the NASA site 
Table 1

Geographical, soil and climatic characteristics of sites in India and Mali (West Africa).

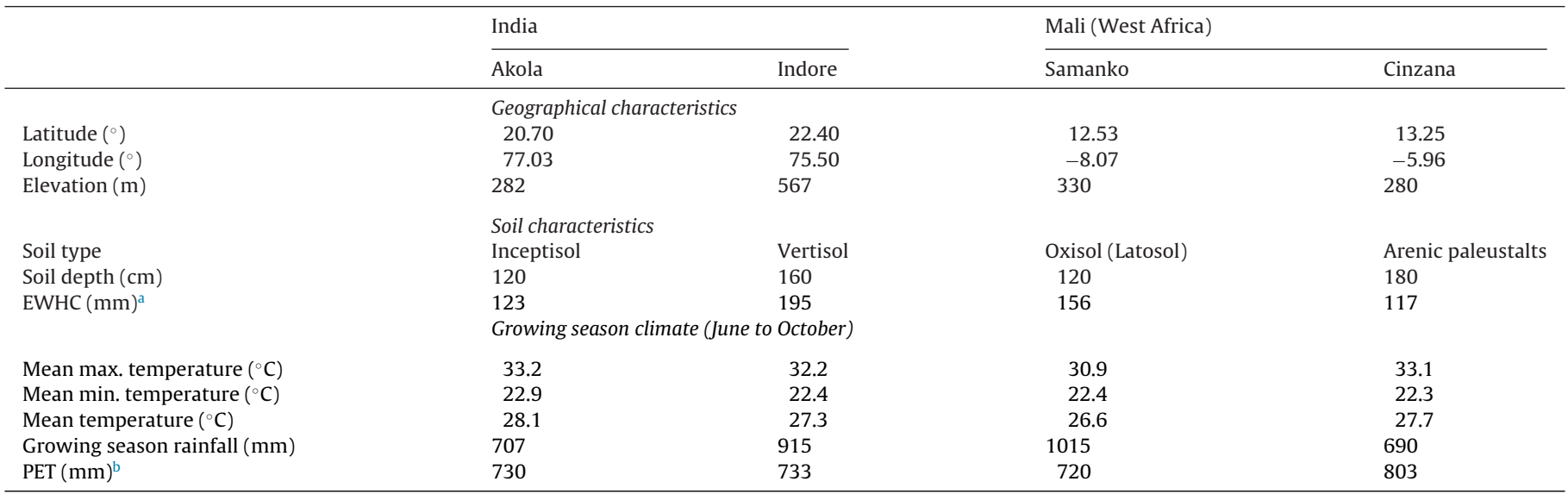

a Extractable water holding capacity of soil.

b Potential evapotranspiration.

(http://earth-www.larc.nasa.gov/cgi-bin/cgiwrap/solar/agro.cgi? email=agroclim@larc.nasa.gov); and the NASA rainfall data was replaced by the measured data of the sites. Soils data were entered in the soils data file ( $\left.{ }^{*} . \mathrm{SOL}\right)$ and the daily weather data in the weather files $\left({ }^{*}\right.$.WTH $)$ for each site.

\subsection{Model adjustments for high temperature conditions}

The current version of the CSM-CERES-Sorghum model in DSSAT v4.5 is not sufficiently sensitive to high temperature conditions for the processes of crop growth and grain yield formation (seed-set and seed growth) determining final yield of susceptible and tolerant cultivars at harvest. As these processes are major determinants of grain yield at high temperatures (Prasad et al., 2006), changes were made in the temperature functions of relative photosynthesis (PCARB) and grain-filling (RGFIL) rates of sorghum as given in the crop-specific parameter file ( ${ }^{*}$.SPE) of the model. The original value of damaging "failure" temperature threshold (Tmax) for PCARB was $50.0^{\circ} \mathrm{C}$. This was set to $44^{\circ} \mathrm{C}$ to increase sensitivity of photosynthesis to high temperatures (Table B.1, Appendix B). This change in sensitivity of photosynthesis had no effect on biomass or yield for any of the available sorghum simulations in the DSSAT (Patancheru, India, 1980; Kunnunurra, Australia, 1982; Tempe, Arizona, 1998/1999; Ouagadougou, Burkina Faso, 2006/2007). For RGFIL, the original values of the upper side optimum temperature (Topt2) and the damaging "failure" temperature threshold (Tmax) were $44^{\circ} \mathrm{C}$ and $50.0^{\circ} \mathrm{C}$, respectively. By comparison to data of Prasad et al. (2006), these two upper-side default values for the RGFIL function in the CSM-CERES-Sorghum were unrealistically high, having never been tested. Sunlit controlled-environment studies by Prasad et al. (2006) indicated the optimum temperature for sorghum grain yield was $27^{\circ} \mathrm{C}$ or below, and that failure temperature for zero grain yield (and seed-set) was $35^{\circ} \mathrm{C}$. Therefore, for the standard susceptible cultivar, the Topt 2 for RGFIL was set to $27^{\circ} \mathrm{C}$ and the Tmax was set to $35^{\circ} \mathrm{C}$ (Table B.1, Appendix B). The temperature response was not calibrated to data of Prasad et al. (2006), but rather their reported values were just accepted as values for optimum versus failure of seed growth rate for the RGFIL function. Fig. 1 shows how the model simulated sorghum yield and seed size response to temperature treatments compared to the sunlit controlled environment data of Prasad et al. (2006), where the cultivar life cycle and seed size for DeKalb $28 \mathrm{E}$ were set for the $32 / 22^{\circ} \mathrm{C}$ treatment, with full incident solar radiation, and a soil fertility factor of 1.00 , but no other adjustments were made. Setting of the RGFIL function was made prior to model evaluation to data of Prasad et al.(2006), so failure to exactly predict the temperature effect on yield and grain size is acceptable, and indicates other aspects of the model that may need improvement, but we wanted to stay with only "read-in" species parameters rather than make source code changes. The RGFIL modifications were subjected to sensitivity analyses with the above listed tropical and subtropical field experiments. The changes to RGFIL (Topt2 from 48 to $27^{\circ} \mathrm{C}$, and Tmax from 50 to $35^{\circ} \mathrm{C}$ ) caused no yield reduction at Patancheru ( $7 \mathrm{~kg} \mathrm{ha}^{-1}$ over three treatments), minor reductions at Kunnunurra $\left(11 \mathrm{kgha}^{-1}\right.$ or $0.2 \%$ over three treatments), $96 \mathrm{~kg} \mathrm{ha}^{-1}$ yield reduction or $2.0 \%$ over eight treatments at
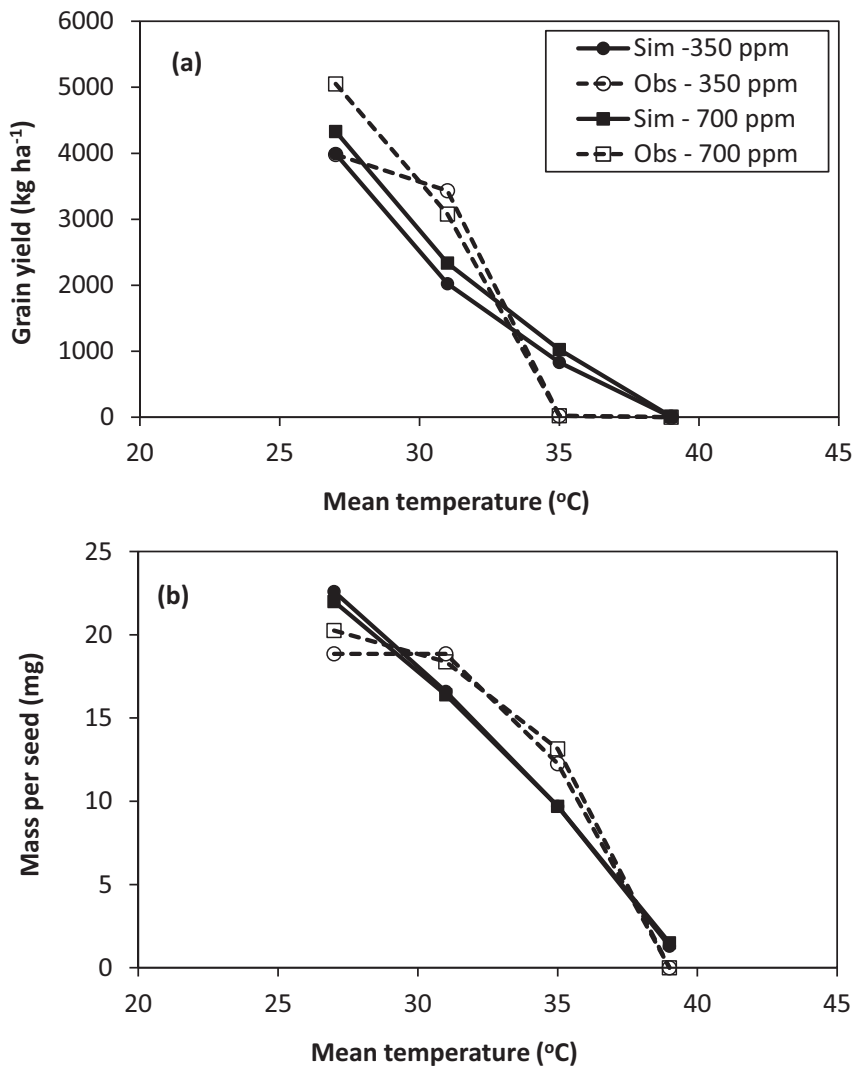

Fig. 1. Simulated (a) grain yield and (b) mass per seed compared with observed data of sorghum grown in two atmospheric $\mathrm{CO}_{2}$ concentrations ( 350 and $700 \mathrm{ppm}$ ) and different mean air temperatures. Observed data obtained from the controlled environment studies of Prasad et al. (2006). Sim, Simulated; Obs, Observed. 
Tempe, Arizona, and $326 \mathrm{~kg} \mathrm{ha}^{-1}$ yield reduction or $10.1 \%$ over 26 treatments at Ouagadougou. This shows that the changes made in Topt 2 and Tmax of RGFIL were appropriate for simulating the yield of a high temperature susceptible sorghum cultivar. For the heat tolerant cultivar, both Topt 2 and Tmax had higher threshold by $2{ }^{\circ} \mathrm{C}$ on RGFIL (Table B.1, Appendix B). A sensitivity test of the $2^{\circ} \mathrm{C}$ more tolerant cultivar gave $0 \%, 0.2 \%, 1.9 \%$, and $6.8 \%$ increases in yield at Patancheru, Kunnunurra, Tempe, and Ouagadougou, where the average temperature during grain filling was $25.9,26.5,28.0$, and $29.4^{\circ} \mathrm{C}$, respectively. The $27^{\circ} \mathrm{C}$ threshold clearly shows to be important. The $2{ }^{\circ} \mathrm{C}$ greater tolerance trait gave an $8 \%$ yield increase at the $36 / 26^{\circ} \mathrm{C}$ treatment of Prasad et al. (2006). Latest DSSAT v4.6 release has these revised temperature thresholds for PCARB and RGFIL.

\subsection{Model calibration of genetic coefficients for baseline cultivars}

For the Indian sites, the cultivar CSV 15 was considered as the most suitable baseline cultivar. In the All India Coordinated Research Project on Sorghum (AICRPS) trials, cultivar CSV 15 was used as one of the national checks at most test sites in India. To determine genetic coefficients of CSV 15, the past crop data (2001-2004) available with ICRISAT and the Advanced Variety Trials data (1994-2008) of AICRPS conducted at six sites in India were used (AICRPS, 1994-2008). The six sites were: Surat (Gujarat), Dharwad (Karnataka), Indore and Parbhani (Maharashtra), Indore (Madhya Pradesh) and Coimbatore (Tamil Nadu). The available agronomic data included sowing date, harvest date, N, P and $\mathrm{K}$ application and number of irrigations given to the crop. The measured data available from the variety trials were days to $50 \%$ flowering (anthesis), days to maturity, seed size, and grain and fodder yield. All the agronomic data were provided in the management file ( ${ }^{*}$.SGX) and the measured data in the observed data file $\left({ }^{*}\right.$.SGA). Each year was considered as a treatment in the management file. A plant population of 18 plants per $\mathrm{m}^{2}$ with a row-to-row spacing of $45 \mathrm{~cm}$, as recommended for rainy season sorghum, was considered for this analysis. At the six sites, sorghum was grown during the rainy season on high water holding capacity Vertisols and associated soils. First, the phenology coefficients were set by several model iterations such that the simulated days to anthesis and physiological maturity matched the observed data across locations. This was achieved by adjusting the coefficients P1 (thermal time from seedling emergence to the end of the juvenile phase), P2O (the longest day length at which development occurs at a maximum rate), and P2R (extent to which phasic development leading to panicle initiation is delayed for each hour increase in photoperiod above P2O) to calibrate days to anthesis and later P5 (thermal time from beginning of grain filling to physiological maturity) to calibrate the days to physiological maturity. Crop canopy expansion, total biomass production and its partitioning to panicle and seeds were set by adjusting the G1 (scale for relative leaf size) and G2 (scale for partitioning of assimilates to the panicle) coefficients. The soil fertility (SLPF) and relative root distribution (SRGF) parameters located in the soil file $\left({ }^{*} . \mathrm{SOL}\right)$ were also set to match the simulated yields with the observed data both for the water-stressed and non-stressed conditions. The SLPF values used were $0.85,0.95,0.86,0.75,0.95$ and 0.68 for Indore, Surat, Akola, Parbhani, Dharwad and Coimbatore, respectively. Since the weather and soils data used for simulation did not belong exactly to the trial sites and the information on agronomic management and crop growth during the season had some gaps, we calibrated the genetic coefficients such that the maximum, minimum and mean grain yields simulated by the model were mostly within $15 \%$ of the reported maximum, minimum and mean grain yields for the sites. We assumed that the maximum yields were obtained without any major abiotic or biotic constraints, while minimum yields were obtained under the overriding impact of drought. Thus, we established that the maximum rain-fed potential yield, the minimum yield and the mean yield for each site are simulated accurately.

For the sites in Mali, the cultivars CSM 335 and CSM 63E were considered as the baseline cultivars. The crop phenology and yield data for these cultivars were available from agronomic trials conducted during 2005-2008 at Samanko. In these trials the cultivars CSM 335 and CSM 63E were grown at various plant populations and sowing dates under high fertility management $(100-120 \mathrm{~kg} \mathrm{~N}$ and 20-40 kg P ha ${ }^{-1}$ application rates). Additional data were also available from the multi-location plant breeding trials conducted during 2006-2010 at Samanko, Kolombada, Wobougou and Keniero sites in Mali, wherein cultivars CSM 335 and CSM 63E were included as checks. From these multi-location trials, only crop yield data recorded under only high fertility management $(40-60 \mathrm{~kg} \mathrm{~N}$ and 20-50 kg P ha ${ }^{-1}$ application rates) were considered for calibration of the two cultivars. The SLPF values used were $0.68,0.64,0.60$ and 0.53 for the Samanko, Kolombada, Wobougou and Keniero sites, respectively. The sorghum crop in all the trials in Mali was grown rainfed. The calibration procedure for the CSM 335 and CSM $63 \mathrm{E}$ cultivars was the same as for the CSV 15 cultivar. The genetic coefficients of the three baseline cultivars used in this study are presented in Appendix C.

\subsection{Development of virtual cultivars}

\subsubsection{Crop life cycle and yield potential}

For each baseline cultivar three life cycles (crop maturity durations) were considered for developing virtual cultivars - baseline (no change in the genetic coefficients of the baseline cultivar), 10\% shorter and $10 \%$ longer maturity cultivars. To make changes in the crop duration, the genetic coefficients P1 (thermal time from seedling emergence to the end of the juvenile phase), P2O (critical photoperiod or the longest day length (in $h$ ) at which development occurs at a maximum rate) and P5 (thermal time from beginning of grain filling to physiological maturity) located in the cultivar file ${ }^{*}$.CUL) were altered. To decrease the crop duration by $10 \%, \mathrm{P} 1$ was decreased and $\mathrm{P} 2 \mathrm{O}$ increased to have $10 \%$ reduction in days to anthesis and the value of P5 was decreased to have an overall $10 \%$ reduction in days to physiological maturity. For the $10 \%$ longer duration cultivar; P1 was increased, P2O was decreased and P5 was increased. To increase the yield potential of cultivars, coefficients G1 (scale for relative leaf size) and G2 (scale for partitioning of assimilates to the panicle) coefficients in the cultivar file and RUE (radiation use efficiency) in the ecotype file ( ${ }^{*}$.ECO) were increased by $10 \%$ each.

\subsubsection{Drought tolerance}

To enhance drought tolerance of cultivars, changes were made in the relative root length density distribution with depth (WR) and the lower limits of water availability (LL) for each soil layer in the soil file ( $\left.{ }^{*} . S O L\right)$. Currently, the WR for different soil layers is estimated as per the following exponential equation:

$\mathrm{WR}(L)=\operatorname{EXP}(-0.02 * Z(L))$

where $\mathrm{Z}(\mathrm{L})$ is the depth to the midpoint of the soil layer L. Drought tolerant cultivars were assumed to have higher rooting density at depth for greater ability to extract soil water (Jordan et al., 1983). The deeper root length density distribution was computed by the following power equation:

$\mathrm{WR}(L)=\left[1.0-\frac{Z(L)}{5}\right]^{p}$

where the value 5 (in meters) was used for all soils and $p$ was equal to 6 . This progressively increased WR (over the default) with 
Table 2

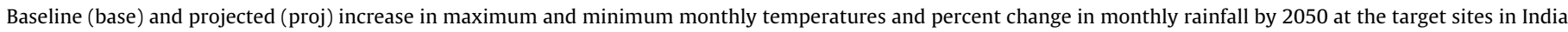
and Mali as per the UKMO-HADCM3 GCM model for the SRES A1B scenario.

\begin{tabular}{|c|c|c|c|c|c|c|c|c|}
\hline \multirow[t]{3}{*}{ Month } & \multicolumn{2}{|l|}{ Akola } & \multicolumn{2}{|l|}{ Indore } & \multicolumn{2}{|l|}{ Samanko } & \multicolumn{2}{|l|}{ Cinzana } \\
\hline & Base & Proj & Base & Proj & Base & Proj & Base & Proj \\
\hline & 1968-1998 & $2050^{\mathrm{a}}$ & 1975-2004 & 2050 & 1997-2010 & 2050 & $1983-2010$ & 2050 \\
\hline & \multicolumn{8}{|c|}{ Maximum temperature $\left({ }^{\circ} \mathrm{C}\right)$} \\
\hline June-October & $30.4-37.3$ & $1.0-2.3$ & $29.1-36.8$ & $0.2-1.7$ & $28.7-33.0$ & $2.8-4.0$ & $31.0-35.8$ & $2.8-4.0$ \\
\hline \multirow[t]{2}{*}{ June-October } & \multicolumn{8}{|c|}{ Minimum temperature $\left({ }^{\circ} \mathrm{C}\right)$} \\
\hline & \multicolumn{8}{|c|}{ Rainfall (mm) and \% change } \\
\hline June & 143 & -33 & 149 & -65 & 170 & -13 & 103 & -10 \\
\hline July & 192 & 17 & 275 & 22 & 228 & -6 & 182 & -5 \\
\hline August & 197 & 12 & 280 & 17 & 315 & -2 & 234 & 1 \\
\hline September & 125 & 27 & 170 & 54 & 223 & -1 & 132 & 3 \\
\hline October & 50 & 30 & 41 & 47 & 79 & -6 & 38 & -5 \\
\hline Total & 707 & & 915 & & 1015 & & 690 & \\
\hline
\end{tabular}

a 2040-2069 averaging period.

depth in the soil profile for greater soil water extraction. In addition to increased WR with depth, the available water in each soil layer was increased by $5 \%$ by reducing the lower limit (LL) of soil water extraction as follows: $\mathrm{LL}(\mathrm{TOL})=\mathrm{LL}-0.05^{*}(\mathrm{DUL}-\mathrm{LL})$, where $\mathrm{LL}(\mathrm{TOL})$ is the LL for the drought tolerant cultivar and DUL is the drained upper limit. The presumption is that a drought tolerant cultivar can extract water at a higher tension from each given layer (Passioura, 1983).

\subsubsection{Heat tolerance}

Currently heat tolerance is not a cultivar coefficient in the sorghum model, but rather is a species-wide trait described in the species file. Heat tolerance of sorghum was increased by increasing the two temperature threshold values of RGFIL (relative grain filing rate) located in the species file $\left({ }^{*} . \mathrm{SPE}\right)$ each by $2{ }^{\circ} \mathrm{C}$, i.e., the upper optimum temperature threshold (TOP2) value was increased from 27 to $29^{\circ} \mathrm{C}$ and the damaging (failure) temperature threshold (TMAX) value increased from 35 to $37^{\circ} \mathrm{C}$ (Table B.1).

\subsection{Projected climate change at the target sites}

Statistically downscaled (delta method) projected climate data as per the UKMO-HADCM3 GCM model for the SRES A1B scenario for the 2050 (2040-2069) time slice and the WorldClim baseline (1960-90) climate data were downloaded from CIAT's climate change portal (http://ccafs-climate.org/ download_sres.html\#down). The spatial resolution of the projected climate data was 2.5 arc-minute $\left(5 \mathrm{~km}^{2}\right)$ and that of baseline data was 30 arc-second $\left(1 \mathrm{~km}^{2}\right)$. Based on the latitude and longitude of the target sites, the required data were extracted from these two databases. The difference between the projected monthly maximum and minimum temperatures by 2050 and the baseline values gave the "delta" changes in temperature. The percent deviations in monthly rainfall from the baseline values were also calculated (Table 2). Monthly changes in maximum and minimum temperature and rainfall along with $\mathrm{CO}_{2}$ increase as per the ISAM model (IPCC, 2001) were input to the 'environmental modifications section' of the management files of sorghum (.SGX). Temperatures were entered as change in temperature, rainfall as ratio of projected rainfall to baseline rainfall and $\mathrm{CO}_{2}$ as absolute value against first day of each month. During the simulation process the observed baseline daily weather data of a given month was modified with the projected climate change values of that month starting with the first day of each month.

\subsection{Simulating the impact of climate change and genetic traits}

The CSM-CERES-Sorghum simulation model coupled with the seasonal analysis program available in DSSAT v4.5 was used to simulate the impact of climate change on sorghum productivity. Simulations were carried out for the baseline climate and the projected climate change of 2050 "slice" for each site. The impacts of change in temperature (temp.), changes in temperature and $\mathrm{CO}_{2}$ (temp. $+\mathrm{CO}_{2}$ ) and changes in temperature, $\mathrm{CO}_{2}$ and rainfall (temp. $+\mathrm{CO}_{2}+$ rain) were evaluated separately to quantify the impact of each successive factor. The atmospheric $\mathrm{CO}_{2}$ concentration considered was $380 \mathrm{ppm}$ for the baseline climate and $530 \mathrm{ppm}$ for the 2050 climate projections (IPCC, 2001).

For the Indian sites, the simulations were initiated on 1 January each year and the soil profile on that day was considered to be at the upper limit of soil water availability (DUL). Considering the onset of rainy season after the long dry period, sowing window assumed was 6 July to 30 August for Akola and 23 June to 15 August for Indore each year. The simulated crop was sown on the day when the soil moisture content in the top $30-\mathrm{cm}$ soil depth had reached at least $40 \%$ of the extractable water-holding capacity during the sowing window. A plant population of 18 plants per $\mathrm{m}^{2}$ with a rowto-row spacing of $45 \mathrm{~cm}$ was considered for simulating sorghum growth. Di-ammonium phosphate at $100 \mathrm{~kg} \mathrm{ha}^{-1}$ was applied to supply $20 \mathrm{~kg} \mathrm{~N}$ and $20 \mathrm{~kg}$ P per ha at the time of sowing. Additional doses of $30 \mathrm{~kg} \mathrm{~N} \mathrm{ha}^{-1}$ each were applied as urea at 30 and 60 days after sowing. The SLPF (soil-limited photosynthesis factor) values were 0.86 and 0.85 for Akola and Indore, respectively. The simulations were carried out for 30 years each for Akola (1969-1998) and Indore (1975-2004).

For the Samanko and Cinzana sites, simulations were initiated on 15 May each year and the soil profile was considered to be at the lower limit (LL) of soil water availability on that day. The sowing window was 25 June to 20 July. The crop was sown on the day when the soil moisture content in the top $60 \mathrm{~cm}$ soil depth had reached at least $55 \%$ of the extractable water-holding capacity during the sowing window. Plant population, row-to-row spacing and nutrient management were the same as for the Indian sites. The SLPF value was 0.68 for Samanko and 0.74 for Cinzana. Simulations were carried out for 14 years (1997-2010) for Samanko and 28 years (1983-2010) for Cinzana. The crop was simulated as rainfed at all the sites in India and Mali. As the sorghum model does not account for the effects of pests and diseases on crop growth and yield, the crop was considered free from pests and diseases.

All the simulated data were analyzed by following the analysis of variance (ANOVA) method using GenStat software (Payne et al., 
Table 3

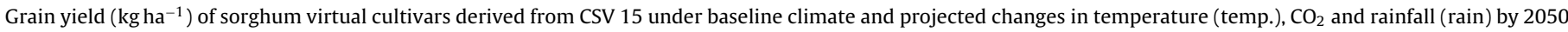
at Akola, India.

\begin{tabular}{|c|c|c|c|c|c|c|c|c|c|c|c|}
\hline \multirow[t]{2}{*}{ Cultivar } & \multicolumn{4}{|c|}{ Baseline climate } & \multicolumn{2}{|c|}{ Temp. } & \multicolumn{2}{|c|}{ Temp. $+\mathrm{CO}_{2}$} & \multicolumn{2}{|c|}{ Temp. $+\mathrm{CO}_{2}+$ rain } & \multirow[b]{2}{*}{$\operatorname{LSD}(0.05)^{\mathrm{b}}$} \\
\hline & AN & PM & Yield & $\% \mathrm{Ch}$. & Yield & $\% \mathrm{Ch}$. & Yield & $\% \mathrm{Ch}$. & Yield & $\% \mathrm{Ch}$. & \\
\hline Baseline & 71 & 108 & 3790 & - & 2902 & - & 3070 & - & 3127 & - & 113 \\
\hline $10 \%$ shorter & 65 & 99 & 3177 & -16 & 2277 & -22 & 2466 & -20 & 2494 & -20 & 86 \\
\hline $10 \%$ longer & 78 & 120 & 3939 & 4 & 3238 & 12 & 3368 & 10 & 3449 & 10 & 124 \\
\hline Base + YP & 71 & 108 & 4389 & $16^{\mathrm{a}}$ & 3569 & $23^{a}$ & 3728 & $21^{\mathrm{a}}$ & 3785 & $21^{\mathrm{a}}$ & 108 \\
\hline $10 \%$ shorter + YP & 65 & 99 & 3994 & $26^{a}$ & 3019 & $33^{a}$ & 3202 & $30^{\mathrm{a}}$ & 3236 & $30^{\mathrm{a}}$ & 93 \\
\hline $10 \%$ longer $+\mathrm{YP}$ & 78 & 120 & 4382 & $11^{\mathrm{a}}$ & 3807 & $18^{\mathrm{a}}$ & 3922 & $16^{\mathrm{a}}$ & 4004 & $16^{\mathrm{a}}$ & 134 \\
\hline $\operatorname{LSD}(0.05)^{\mathrm{b}}$ & & & 218 & & 191 & & 187 & & 183 & & \\
\hline
\end{tabular}

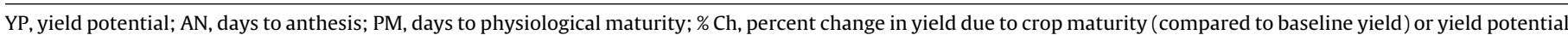
traits within a climate.

a Percent yield improvement due to enhanced yield potential traits as compared to the cultivar with same crop maturity within a climate.

b Least significant difference $\left(\mathrm{kg} \mathrm{ha}^{-1}\right)$ at $5 \%$ level of probability to compare yields within the same column or row.

2009). Analyses were carried out to compare the performance of virtual cultivars within climate scenarios, or to compare the performance of a single virtual cultivar or tolerance trait across climate scenarios. To analyze data, the randomized complete block design (RCBD) was followed and the least significant differences at $5 \%$ level of probability were calculated to compare the treatments. Years were considered as replications (blocks), as the sorghum yield in one year under a given treatment was not affected by another year (prior year carry-over of soil water was not simulated).

\section{Results}

Simulated values of grain yields for the baseline cultivars were significantly correlated with observed data (CSV 15: $y=1.04 x-137.2 ; \quad \operatorname{RSME}=366 ; R^{2}=0.91 ; \quad \operatorname{CSM} 335$ : $y=1.04 x-214.6 ; \mathrm{RSME}=338 ; R^{2}=0.85 ;$ CSM 63E: $y=0.95 x+74.4$; RSME $=216 ; R^{2}=0.86$ ) (Fig. 2). The $d$-value, a measure of model predictability (Willmott, 1982), was also high for the cultivars ( 0.97 for CSV 15, 0.95 for CSM 335 and 0.96 for CSM 63E). These results confirm that the genetic coefficients of the cultivars are accurate and that the sorghum model can be reliably used to simulate growth and yield of sorghum in response to climate change factors and genetic modifications for different soil-climate environments of India and Mali.

\subsection{Response to climate scenarios and genetic traits}

\subsubsection{Akola}

At Akola the baseline cultivar CSV 15 took 71 days to anthesis, 108 days to physiological maturity and on average produced $3790 \mathrm{~kg}$ of grain yield per ha under the baseline climate (Table 3). Under the shorter growing cycle, grain yield decreased by $16 \%$ and under longer cycle it increased by $4 \%$. By modifying the yield potential traits (G1, G2 and RUE), the grain yield of the baseline, shorter, and longer maturity cultivars increased by $16 \%, 26 \%$ and $11 \%$, respectively, as compared to their counterparts with lower yieldpotential traits. Under climate change the grain yield of the baseline cultivar decreased by $23 \%$ with the increase in temperature, $19 \%$ with the increase in temperature $+\mathrm{CO}_{2}$ and $18 \%$ with the change in temperature $+\mathrm{CO}_{2}+$ rainfall. Under the three climate change scenarios, the yield of shorter maturity cultivar decreased by $20-22 \%$ and that of longer maturity cultivar increased by $10-12 \%$. Under climate change scenarios, the yield potential traits increased the yield by $21-23 \%$ for the baseline cultivar, 30-33\% for the shorter maturity cultivar and $16-18 \%$ for the longer maturity cultivar as compared to the yield of counterparts without yield potential traits. These changes in yield due to crop maturity or yield potential traits were statistically significant $(P<0.05)$ under the climate change scenarios. Across climate scenarios, the maximum yield was simulated for the $10 \%$ longer maturity cultivar with high yield potential traits. With drought tolerance the yields of virtual cultivars increased by $3-6 \%$ under baseline climate and 3-4\% under climate change as compared to the baseline yield of their counterparts without drought tolerance trait (Table 4). The benefit of incorporating heat tolerance was up to a $4 \%$ increase in yield under baseline climate and up to $12 \%$ under climate change. These results indicate that yield gains of virtual cultivars were greater with drought tolerance than with heat tolerance under current climate; however under future climate heat tolerance will be more important than drought tolerance for sustaining yields at Akola. The combined benefit of drought and heat tolerance traits across the virtual cultivars ranged from $5 \%$ to $8 \%$ increase in yield under baseline climate and $13-17 \%$ under climate change as compared to the yield of their counterparts without tolerance traits incorporated.

\subsubsection{Indore}

At Indore the baseline cultivar CSV 15 took 75 days to anthesis, 115 days to physiological maturity and on average produced $3540 \mathrm{~kg}$ of grain yield per ha under the baseline climate (Table 5). With shorter maturity the grain yield decreased by $15 \%$ and with longer maturity it increased by $4 \%$. By modifying the yield potential traits, the grain yield of baseline, shorter, and longer maturity cultivars increased by $19 \%, 23 \%$ and $18 \%$, respectively, as compared to their counterparts with lower yield-potential traits. Under climate change, the grain yield of baseline cultivar decreased by $7 \%$ with increase in temperature, $1 \%$ with the increase in temperature $+\mathrm{CO}_{2}$ and $6 \%$ with the change in temperature $+\mathrm{CO}_{2}+$ rainfall. Under the three climate change scenarios, the yield of the shorter maturity cultivar decreased up to $22 \%$ and increased up to $9 \%$ for the longer maturity. Under climate change scenarios, the yield potential traits increased the yield by $20-22 \%$ for the baseline cultivar, $26-30 \%$ for the shorter maturity and $17-19 \%$ for the longer maturity cultivar as compared the yield of their counterparts without yield potential traits. These differences in yield of virtual cultivars under the climate scenarios due to crop maturity and yield potential traits were statistically significant $(P<0.05)$. Maximum yield was simulated for the longer maturity cultivar with high yield potential traits under both baseline climate and climate change. With drought tolerance the yield of virtual cultivars increased by $4-10 \%$ under baseline climate and $2-8 \%$ under climate change as compared to the yield of their counterparts without drought tolerance trait (Table 6). Generally the higher benefit due to drought tolerance was associated with longer maturity cultivars than the baseline or the shorter maturity cultivar. The yield benefit due to this trait decreased under climate change because of projected increase in rainfall for the site during July to October. Incorporating heat tolerance did not benefit the crop under baseline climate; whereas under climate change, this benefit was only up to $3 \%$ increase in yield for the 
Table 4

Effect of incorporating drought and heat tolerance traits on the mean grain yield ( $\left.\mathrm{kg} \mathrm{ha}^{-1}\right)$ of virtual sorghum cultivars derived from CSV 15 at Akola, India.

\begin{tabular}{|c|c|c|c|c|c|c|c|c|}
\hline \multirow[t]{2}{*}{ Cultivar } & \multirow[b]{2}{*}{ Baseline yield } & \multicolumn{2}{|c|}{ Drought tolerance } & \multicolumn{2}{|c|}{ Heat tolerance } & \multicolumn{2}{|c|}{ Drought + heat tolerance } & \multirow[b]{2}{*}{$\operatorname{LSD}(0.05)^{\mathrm{a}}$} \\
\hline & & Yield & $\%$ Change & Yield & $\%$ Change & Yield & $\%$ Change & \\
\hline & Baseline climate & & & & & & & \\
\hline Baseline & 3790 & 3978 & 5 & 3885 & 2 & 4077 & 8 & 60 \\
\hline $10 \%$ shorter & 3177 & 3281 & 3 & 3307 & 4 & 3422 & 8 & 52 \\
\hline $10 \%$ longer & 3939 & 4164 & 6 & 3992 & 1 & 4204 & 7 & 37 \\
\hline Base + YP & 4389 & 4613 & 5 & 4458 & 2 & 4664 & 6 & 47 \\
\hline $10 \%$ shorter $+\mathrm{YP}$ & 3994 & 4125 & 3 & 4088 & 2 & 4227 & 6 & 54 \\
\hline \multirow[t]{2}{*}{$10 \%$ longer $+\mathrm{YP}$} & 4382 & 4615 & 5 & 4401 & 0 & 4612 & 5 & 43 \\
\hline & \multicolumn{8}{|c|}{ Climate change (temperature $+\mathrm{CO}_{2}+$ rain) } \\
\hline Baseline & 3127 & 3229 & 3 & 3466 & 11 & 3579 & 14 & 55 \\
\hline $10 \%$ shorter & 2494 & 2565 & 3 & 2730 & 9 & 2815 & 13 & 45 \\
\hline $10 \%$ longer & 3449 & 3604 & 4 & 3850 & 12 & 4031 & 17 & 77 \\
\hline Base + YP & 3785 & 3910 & 3 & 4179 & 10 & 4329 & 14 & 69 \\
\hline $10 \%$ shorter $+\mathrm{YP}$ & 3236 & 3331 & 3 & 3548 & 10 & 3643 & 13 & 57 \\
\hline 10\% longer + YP & 4004 & 4183 & 4 & 4324 & 8 & 4555 & 14 & 81 \\
\hline
\end{tabular}

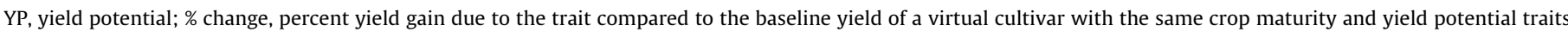
within climate scenario.

a Least significant difference ( $\mathrm{kg} \mathrm{ha}^{-1}$ ) at $5 \%$ level of probability to compare yields within the same row.

Table 5

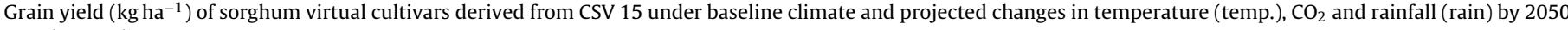
at Indore, India.

\begin{tabular}{|c|c|c|c|c|c|c|c|c|c|c|c|}
\hline \multirow[t]{2}{*}{ Cultivar } & \multicolumn{4}{|c|}{ Baseline climate } & \multicolumn{2}{|c|}{ Temp. } & \multicolumn{2}{|c|}{ Temp. $+\mathrm{CO}_{2}$} & \multicolumn{2}{|c|}{ Temp. $+\mathrm{CO}_{2}+$ rain } & \multirow[b]{2}{*}{$\operatorname{LSD}(0.05)^{\mathrm{b}}$} \\
\hline & AN & PM & Yield & $\%$ Ch. & Yield & $\%$ Ch. & Yield & $\% \mathrm{Ch}$. & Yield & $\%$ Ch. & \\
\hline Baseline & 75 & 115 & 3540 & - & 3280 & - & 3498 & - & 3329 & - & 111 \\
\hline $10 \%$ shorter & 67 & 104 & 3016 & -15 & 2582 & -21 & 2800 & -20 & 2589 & -22 & 122 \\
\hline $10 \%$ longer & 82 & 126 & 3688 & 4 & 3574 & 9 & 3781 & 8 & 3624 & 9 & 114 \\
\hline Base + YP & 75 & 115 & 4213 & $19^{\mathrm{a}}$ & 3985 & $22^{\mathrm{a}}$ & 4197 & $20^{\mathrm{a}}$ & 4051 & $22^{\mathrm{a}}$ & 115 \\
\hline $10 \%$ shorter $+\mathrm{YP}$ & 67 & 104 & 3718 & $23^{a}$ & 3280 & $27^{a}$ & 3516 & $26^{a}$ & 3355 & $30^{\mathrm{a}}$ & 119 \\
\hline $10 \%$ longer $+\mathrm{YP}$ & 82 & 126 & 4360 & $18^{\mathrm{a}}$ & 4207 & $18^{a}$ & 4427 & $17^{\mathrm{a}}$ & 4308 & $19^{a}$ & 98 \\
\hline $\operatorname{LSD}(0.05)^{\mathrm{b}}$ & & & 132 & & 121 & & 124 & & 119 & & \\
\hline
\end{tabular}

For explanation of abbreviations and footnotes, see Table 3.

shorter maturity cultivar without yield potential trait. These results show that drought tolerance, rather than temperature tolerance, is an important trait for sorghum at Indore under both the current and future climates. Combining drought and heat tolerance under both baseline and climate change did not improve the yields above those simulated with drought tolerance for each virtual cultivar.

\subsubsection{Samanko}

At Samanko the baseline cultivar CSM 335 took 81 days to anthesis, 120 days to physiological maturity and on average produced $2700 \mathrm{~kg}$ of grain yield per ha under the baseline climate (Table 7). Under shorter maturity, grain yield decreased by $8 \%$ and under longer maturity it increased by $4 \%$. By modifying the yield potential traits, the grain yield of baseline, shorter, and longer maturity cultivars increased by $11 \%, 14 \%$ and $10 \%$, respectively, as compared to their counterparts with lower yield-potential traits. Under climate change, the grain yield of baseline cultivar decreased by $14 \%$ with the increase in temperature, $12 \%$ with the increase in temperature $+\mathrm{CO}_{2}$ and $12 \%$ with temperature $+\mathrm{CO}_{2}+$ rainfall. Under the three climate change scenarios, the yield of the shorter maturity cultivar decreased by $21-24 \%$ and for the longer maturity cultivar increased up to $8 \%$ as compared to the yield of the baseline cultivar within the climate scenario. Under climate change, the benefits of yield potential traits increased up to $15 \%$ for the baseline cultivar, $23-27 \%$ for the shorter maturity cultivar and up to $12 \%$ for the longer maturity cultivar as compared to the yield of

Table 6

Effect of incorporating drought and heat tolerance traits on the mean grain yield ( $\left.\mathrm{kg} \mathrm{ha}^{-1}\right)$ of virtual sorghum cultivars derived from CSV 15 at Indore, India.

\begin{tabular}{|c|c|c|c|c|c|c|c|c|}
\hline \multirow[t]{2}{*}{ Cultivar } & \multirow[b]{2}{*}{ Baseline yield } & \multicolumn{2}{|c|}{ Drought tolerance } & \multicolumn{2}{|c|}{ Heat tolerance } & \multicolumn{2}{|c|}{ Drought + heat tolerance } & \multirow[b]{2}{*}{$\operatorname{LSD}(0.05)^{\mathrm{a}}$} \\
\hline & & Yield & $\%$ Change & Yield & $\%$ Change & Yield & $\%$ Change & \\
\hline & Baseline climate & & & & & & & \\
\hline Baseline & 3540 & 3779 & 7 & 3542 & 0 & 3774 & 7 & 66 \\
\hline $10 \%$ shorter & 3016 & 3147 & 4 & 3037 & 1 & 3166 & 5 & 58 \\
\hline $10 \%$ longer & 3688 & 4065 & 10 & 3679 & 0 & 4056 & 10 & 70 \\
\hline Base + YP & 4213 & 4502 & 7 & 4195 & 0 & 4476 & 6 & 67 \\
\hline $10 \%$ shorter + YP & 3718 & 3865 & 4 & 3723 & 0 & 3876 & 4 & 59 \\
\hline \multirow[t]{2}{*}{ 10\% longer + YP } & 4360 & 4746 & 9 & 4313 & -1 & 4732 & 9 & 100 \\
\hline & \multicolumn{7}{|c|}{ Climate change (temperature $+\mathrm{CO}_{2}+$ rain) } & \\
\hline Baseline & 3329 & 3482 & 5 & 3364 & 1 & 3516 & 6 & 82 \\
\hline $10 \%$ shorter & 2589 & 2667 & 3 & 2654 & 3 & 2737 & 6 & 66 \\
\hline $10 \%$ longer & 3624 & 3910 & 8 & 3648 & 1 & 3939 & 9 & 69 \\
\hline Base + YP & 4051 & 4234 & 4 & 4065 & 0 & 4245 & 5 & 77 \\
\hline $10 \%$ shorter $+\mathrm{YP}$ & 3355 & 3432 & 2 & 3390 & 1 & 3475 & 4 & 82 \\
\hline $10 \%$ longer $+\mathrm{YP}$ & 4308 & 4625 & 7 & 4301 & 0 & 4606 & 7 & 85 \\
\hline
\end{tabular}

For explanation of abbreviations and footnote, see Table 4. 

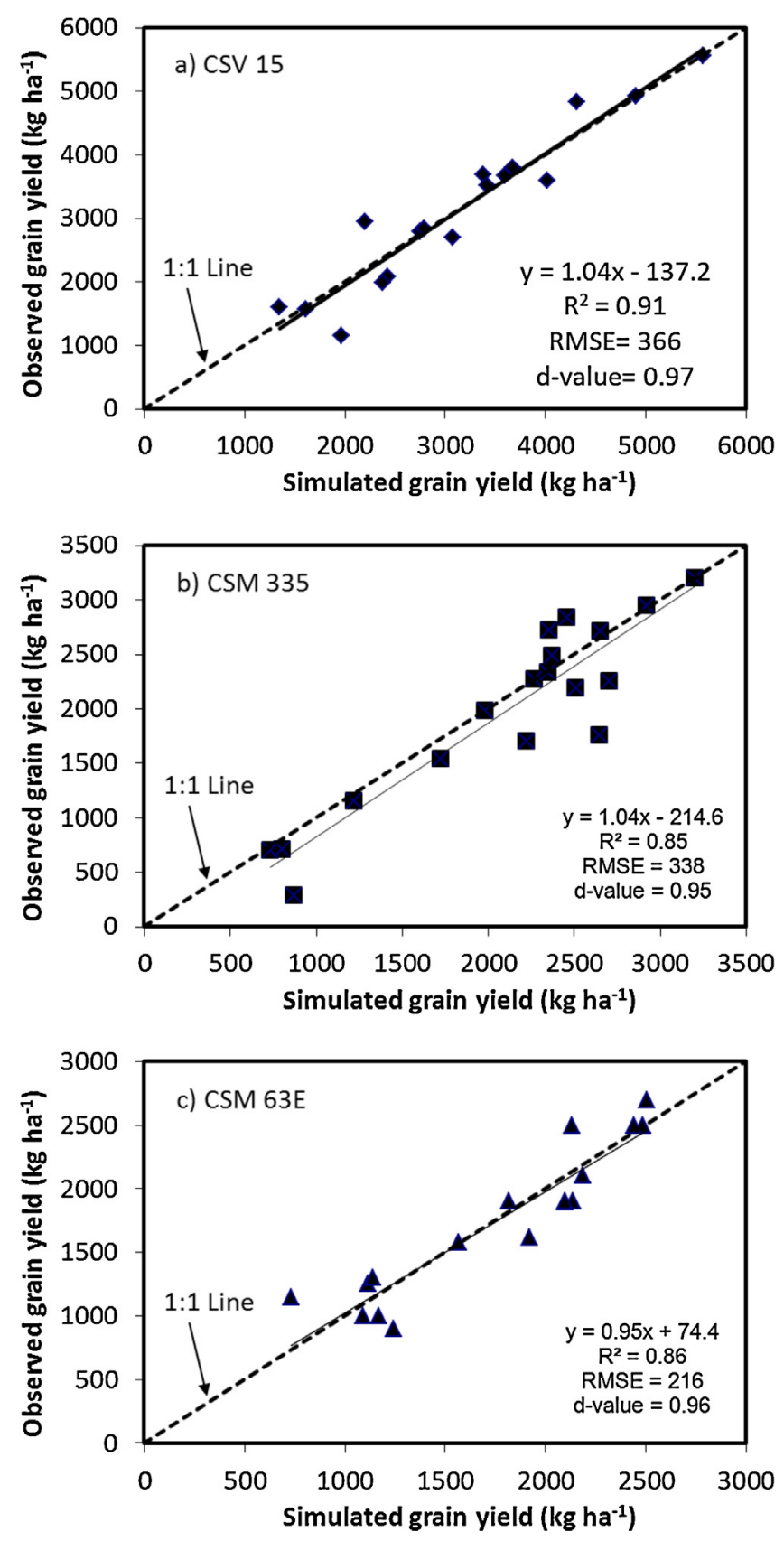

Fig. 2. Relationship of simulated grain yield with observed yield of sorghum for (a) CSV 15, (b) CSM 335 and (c) CSM 63E cultivars used in the study. Observed data for CSV 15 ( $n=18)$ were obtained from the AICRPS reports (AICRPS, 1994-2008) on advanced variety trials conducted at six sites in India. For CSM $335(n=18)$ and CSM 63E $(n=17)$ the observed yield data were obtained from the agronomic trials conducted during 2005-2008 at Samanko, Mali, and plant breeding trials conducted during 2006-2010 at Samanko, Kolombada, Wobougou and Keniero sites in Mali (Sibiry Traore, pers. Comm.).

counterparts without yield potential traits. The much larger effect of yield potential traits for short maturity cultivar may be related to the beneficial effect of increased RUE and other traits to recover productivity associated with shorter vegetative growth and lower leaf area index. All these changes in yield of virtual cultivars due to maturity duration or yield potential traits were statistically significant $(P<0.05)$ under both baseline climate and climate change. Across the climate scenarios, the maximum yield was simulated for the longer maturity cultivar with high yield potential traits incorporated. Incorporating drought tolerance did not benefit the crop under both the baseline climate and climate change (Table 8).
Incorporating heat tolerance did not benefit the crop under the baseline climate; however, the benefit increased up to $7 \%$ under climate change. The combined benefits of drought and heat tolerance across virtual cultivars was up to $2 \%$ increase in yield under baseline climate and up to $7 \%$ under climate change as compared to the yield of their counterparts without these traits incorporated.

\subsubsection{Cinzana}

At Cinzana the baseline cultivar CSM 63E took 63 days to anthesis, 85 days to physiological maturity and on average produced $2210 \mathrm{~kg}$ of grain yield per ha under the baseline climate (Table 9). With shorter maturity the grain yield decreased by $26 \%$ and with longer maturity it increased by $20 \%$. By modifying the yield potential traits, the grain yield of baseline, shorter, and longer maturity cultivars increased by $22 \%, 36 \%$ and $14 \%$, respectively, as compared to their counterparts with lower yield-potential traits. Under climate change, the grain yield of baseline cultivar decreased by $36 \%$ with the increase in temperature, $30 \%$ with the increase in temperature $+\mathrm{CO}_{2}$ and $30 \%$ with temperature $+\mathrm{CO}_{2}+$ rainfall. With the three climate change effects, the yield of the shorter maturity cultivar decreased up to $39 \%$ and for the longer maturity cultivar increased up to $33 \%$, indicating that longer maturity cultivars will be more suitable under climate change at Cinzana. Under climate change scenarios, the benefits of yield potential traits ranged from $28 \%$ to $34 \%$ for the baseline cultivar, $46-51 \%$ for the shorter maturity cultivar and up to $25 \%$ for the longer maturity cultivar as compared the yield of counterparts without yield potential traits. All these changes in yield of virtual cultivars due to maturity duration or yield potential traits were statistically significant $(P<0.05)$ under both baseline and climate change. Across the climate scenarios, the maximum yield was simulated for the longer maturity cultivar with high yield potential traits incorporated. When drought tolerance was incorporated in the virtual cultivars, the yields increased up to $6 \%$ under both the baseline climate and climate change as compared to their counterparts without drought tolerance (Table 10). Incorporating heat tolerance increased the yield of virtual cultivars up to $3 \%$ under baseline climate and up to $9 \%$ under climate change. All yield increases of virtual cultivars due to drought or heat tolerance were statistically significant $(P<0.05)$. The combined benefits of drought and heat tolerance across virtual cultivars were up to $9 \%$ under baseline climate and 9-16\% under climate change.

\section{Discussion}

Using the CSM-CERES-Sorghum model, we have quantified the contribution of crop life cycle, yield potential, drought and heat tolerance traits and their combinations on sorghum yield under current and future climates of the target sites in India and Mali. As climate change will alter the length of growing period (LGP) due to changes in rainfall and temperature, the first step to achieve higher yields under genetic adaptation is to fit the maturity duration of crops to the changing LGPs. This will ensure the least possible water and heat stress to the crop during its life cycle, while fully using the season available. The study revealed that under climate change a $10 \%$ longer maturity cultivar will give up to $12 \%$ increases in grain yield at Akola, up to $9 \%$ at Indore, up to $8 \%$ at Samanko and up to $33 \%$ at Cinzana. It is not surprising that longer cycle cultivars are helpful to recover yield under climate change, as the warmer climate typically shortens the life cycle which itself reduces yield. Fitting crop duration to the changed LGPs in future should be an easy adaptation process because sufficient genetic variability exists in maturity traits among sorghum genotypes (Reddy et al., 2006), which can be deployed to match the maturity duration of sorghum cultivars to the periods of water availability under future climate change. 
Table 7

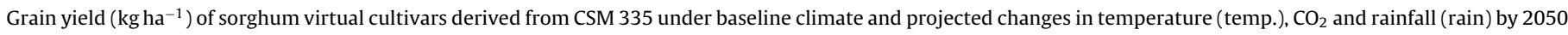
at Samanko, Mali.

\begin{tabular}{|c|c|c|c|c|c|c|c|c|c|c|c|}
\hline \multirow[t]{2}{*}{ Cultivar } & \multicolumn{4}{|c|}{ Baseline climate } & \multicolumn{2}{|c|}{ Temp. } & \multicolumn{2}{|c|}{ Temp. $+\mathrm{CO}_{2}$} & \multicolumn{2}{|c|}{ Temp. $+\mathrm{CO}_{2}+$ rain } & \multirow[b]{2}{*}{$\operatorname{LSD}(0.05)^{\mathrm{b}}$} \\
\hline & AN & PM & Yield & $\% \mathrm{Ch}$. & Yield & $\% \mathrm{Ch}$. & Yield & $\%$ Ch. & Yield & $\% \mathrm{Ch}$. & \\
\hline Baseline & 81 & 120 & 2700 & & 2314 & & 2369 & & 2389 & & 38 \\
\hline $10 \%$ shorter & 73 & 108 & 2484 & -8 & 1759 & -24 & 1876 & -21 & 1899 & -21 & 65 \\
\hline $10 \%$ longer & 90 & 131 & 2816 & 4 & 2499 & 8 & 2532 & 7 & 2551 & 7 & 53 \\
\hline Base + YP & 81 & 120 & 2992 & $11^{\mathrm{a}}$ & 2650 & $15^{\mathrm{a}}$ & 2688 & $13^{\mathrm{a}}$ & 2702 & $13^{a}$ & 39 \\
\hline $10 \%$ shorter $+\mathrm{YP}$ & 73 & 108 & 2839 & $14^{\mathrm{a}}$ & 2235 & $27^{a}$ & 2321 & $24^{\mathrm{a}}$ & 2337 & $23^{a}$ & 58 \\
\hline $10 \%$ longer + YP & 90 & 131 & 3096 & $10^{\mathrm{a}}$ & 2788 & $12^{\mathrm{a}}$ & 2820 & $11^{\mathrm{a}}$ & 2838 & $11^{\mathrm{a}}$ & 64 \\
\hline $\operatorname{LSD}(0.05)^{\mathrm{b}}$ & & & 58 & & 64 & & 57 & & 54 & & \\
\hline
\end{tabular}

For explanation of abbreviations and footnotes, see Table 3.

Table 8

Effect of incorporating drought and heat tolerance traits on the mean grain yield $\left(\mathrm{kg} \mathrm{ha}^{-1}\right)$ of virtual sorghum cultivars derived from CSM 335 at Samanko, Mali.

\begin{tabular}{|c|c|c|c|c|c|c|c|c|}
\hline \multirow[t]{2}{*}{ Cultivar } & \multirow[b]{2}{*}{ Baseline yield } & \multicolumn{2}{|c|}{ Drought tolerance } & \multicolumn{2}{|c|}{ Heat tolerance } & \multicolumn{2}{|c|}{ Drought + heat tolerance } & \multirow[b]{2}{*}{$\operatorname{LSD}(0.05)^{\mathrm{a}}$} \\
\hline & & Yield & $\%$ Change & Yield & $\%$ Change & Yield & $\%$ Change & \\
\hline & Baseline climate & & & & & & & \\
\hline Baseline & 2700 & 2725 & 1 & 2730 & 1 & 2752 & 2 & 16 \\
\hline $10 \%$ shorter & 2484 & 2502 & 1 & 2495 & 0 & 2513 & 1 & 9 \\
\hline $10 \%$ longer & 2816 & 2840 & 1 & 2859 & 2 & 2884 & 2 & 27 \\
\hline Base + YP & 2992 & 3018 & 1 & 3023 & 1 & 3050 & 2 & 23 \\
\hline $10 \%$ shorter + YP & 2839 & 2857 & 1 & 2851 & 0 & 2871 & 1 & 11 \\
\hline \multirow[t]{2}{*}{$10 \%$ longer + YP } & 3096 & 3124 & 1 & 3141 & 1 & 3170 & 2 & 30 \\
\hline & \multicolumn{7}{|c|}{ Climate change (temperature $+\mathrm{CO}_{2}+$ rain) } & \\
\hline Baseline & 2389 & 2395 & 0 & 2531 & 6 & 2538 & 6 & 19 \\
\hline $10 \%$ shorter & 1899 & 1907 & 0 & 1994 & 5 & 2004 & 6 & 15 \\
\hline $10 \%$ longer & 2551 & 2561 & 0 & 2718 & 7 & 2732 & 7 & 20 \\
\hline Base + YP & 2702 & 2711 & 0 & 2865 & 6 & 2874 & 6 & 24 \\
\hline $10 \%$ shorter + YP & 2337 & 2346 & 0 & 2460 & 5 & 2473 & 6 & 22 \\
\hline $10 \%$ longer + YP & 2838 & 2848 & 0 & 3025 & 7 & 3038 & 7 & 24 \\
\hline
\end{tabular}

For explanation of abbreviations and footnote, see Table 4.

Table 9

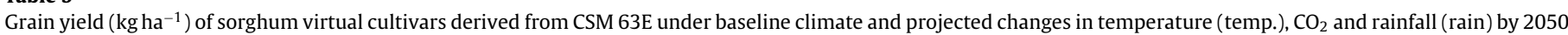
at Cinzana, Mali.

\begin{tabular}{|c|c|c|c|c|c|c|c|c|c|c|c|}
\hline \multirow[t]{2}{*}{ Cultivar } & \multicolumn{4}{|c|}{ Baseline climate } & \multicolumn{2}{|c|}{ Temp. } & \multicolumn{2}{|c|}{ Temp. $+\mathrm{CO}_{2}$} & \multicolumn{2}{|c|}{ Temp. $+\mathrm{CO}_{2}+$ rain } & \multirow[b]{2}{*}{$\operatorname{LSD}(0.05)$} \\
\hline & $\overline{A N}$ & PM & Yield & $\% \mathrm{Ch}$. & Yield & $\% \mathrm{Ch}$. & Yield & $\% \mathrm{Ch}$. & Yield & $\% \mathrm{Ch}$. & \\
\hline Baseline & 63 & 85 & 2210 & - & 1415 & - & 1547 & - & 1540 & - & 61 \\
\hline $10 \%$ shorter & 56 & 78 & 1625 & -26 & 858 & -39 & 974 & -37 & 959 & -38 & 66 \\
\hline $10 \%$ longer & 67 & 94 & 2657 & 20 & 1886 & 33 & 2004 & 30 & 2013 & 31 & 60 \\
\hline Base + YP & 63 & 85 & 2690 & $22^{\mathrm{a}}$ & 1894 & $34^{\mathrm{a}}$ & 1983 & $28^{\mathrm{a}}$ & 1993 & $29^{a}$ & 66 \\
\hline $10 \%$ shorter $+\mathrm{YP}$ & 56 & 78 & 2213 & $36^{\mathrm{a}}$ & 1298 & $51^{\mathrm{a}}$ & 1423 & $46^{\mathrm{a}}$ & 1416 & $48^{a}$ & 66 \\
\hline $10 \%$ longer $+\mathrm{YP}$ & 67 & 94 & 3038 & $14^{\mathrm{a}}$ & 2350 & $25^{a}$ & 2422 & $21^{\mathrm{a}}$ & 2443 & $21^{\mathrm{a}}$ & 68 \\
\hline $\operatorname{LSD}(0.05)^{\mathrm{b}}$ & & & 96 & & 71 & & 72 & & 73 & & \\
\hline
\end{tabular}

For explanation of abbreviations and footnotes, see Table 3.

Table 10

Effect of incorporating drought and heat tolerance traits on the mean grain yield $\left(\mathrm{kg} \mathrm{ha}^{-1}\right)$ of virtual sorghum cultivars derived from CSM 63E at Cinzana, Mali.

\begin{tabular}{|c|c|c|c|c|c|c|c|c|}
\hline \multirow[t]{2}{*}{ Cultivar } & \multirow[b]{2}{*}{ Baseline yield } & \multicolumn{2}{|c|}{ Drought tolerance } & \multicolumn{2}{|c|}{ Heat tolerance } & \multicolumn{2}{|c|}{ Drought + heat tolerance } & \multirow[b]{2}{*}{$\operatorname{LSD}(0.05)^{\mathrm{a}}$} \\
\hline & & Yield & $\%$ Change & Yield & $\%$ Change & Yield & $\%$ Change & \\
\hline & Baseline climate & & & & & & & \\
\hline Baseline & 2210 & 2341 & 6 & 2252 & 2 & 2385 & 8 & 31 \\
\hline $10 \%$ shorter & 1625 & 1711 & 5 & 1640 & 1 & 1726 & 6 & 25 \\
\hline $10 \%$ longer & 2657 & 2814 & 6 & 2740 & 3 & 2898 & 9 & 45 \\
\hline Base + YP & 2690 & 2829 & 5 & 2762 & 3 & 2903 & 8 & 48 \\
\hline $10 \%$ shorter $+\mathrm{YP}$ & 2213 & 2343 & 6 & 2249 & 2 & 2383 & 8 & 36 \\
\hline \multirow[t]{2}{*}{$10 \%$ longer $+\mathrm{YP}$} & 3038 & 3187 & 5 & 3119 & 3 & 3268 & 8 & 51 \\
\hline & \multicolumn{7}{|c|}{ Climate change (temperature $+\mathrm{CO}_{2}+$ rain) } & \\
\hline Baseline & 1540 & 1633 & 6 & 1647 & 7 & 1742 & 13 & 25 \\
\hline $10 \%$ shorter & 959 & 997 & 4 & 1007 & 5 & 1047 & 9 & 14 \\
\hline $10 \%$ longer & 2013 & 2140 & 6 & 2201 & 9 & 2337 & 16 & 35 \\
\hline Base + YP & 1993 & 2107 & 6 & 2159 & 8 & 2295 & 15 & 37 \\
\hline $10 \%$ shorter $+\mathrm{YP}$ & 1416 & 1499 & 6 & 1495 & 6 & 1583 & 12 & 21 \\
\hline $10 \%$ longer $+\mathrm{YP}$ & 2443 & 2575 & 5 & 2662 & 9 & 2792 & 14 & 45 \\
\hline
\end{tabular}

For explanation of abbreviations and footnote, see Table 4. 
Enhancing yield potential of virtual cultivars by increasing RUE, G1 and G2 coefficients each by $10 \%$ increased yields at all four sites. For the longer maturity cultivar, enhanced yield potential traits increased yield up to $18 \%$ at Akola, up to $19 \%$ at Indore, up to $12 \%$ at Samanko and up to $25 \%$ at Cinzana under different climate scenarios as compared to the longer maturity cultivar without the yield potential traits. For baseline and shorter maturity virtual cultivars, the yield gains due to yield potential traits were even larger. Such high yield gains for sorghum should be possible as these estimates are based on both increased source (RUE) and sink size (G1 and G2 coefficients) of sorghum virtual cultivars and such relatively small variation in these plant traits should exist among sorghum genotypes (Reddy et al., 2006; Hammer et al., 2010; Narayanan et al., 2013).

The benefits of incorporating drought tolerance in sorghum were variable across sites depending upon the amount and distribution of rainfall and water retention properties of soils at the target sites. Under baseline climate, the simulated yield gains due to drought tolerance among virtual cultivars were the largest (4-10\%) at Indore, followed by Cinzana (5-6\%), Akola (3-6\%) and negligible at Samanko. Because of the projected increase in rainfall after the month of June at Akola and Indore sites, there were lesser yield gains due to increased drought tolerance under climate change. Similar trend in responses under climate change was simulated for the Samanko site in spite of slight decrease in projected rainfall. However for the Cinzana site, the yield gains due to drought tolerance remained high (4-6\%) under climate change. Although the rainfall is projected to increase at some sites with climate change, the crops may still suffer from drought due to increased water demand caused by higher air temperatures with climate change and also in some years due to low rainfall during the season. Though drought tolerance in sorghum could be attributed to multiple plant traits, increased rooting depth in the soil profile and/or increased root length density (RLD) in the subsoil resulting in greater water extraction during the periods of water stress are suggested as the prominent mechanisms for drought tolerance and higher yields under water stress in sorghum (Jordan et al., 1983; Passioura, 1983; Lafolie et al., 1991). Genotypic variation in sorghum for root traits exists, which can be utilized for developing drought tolerant cultivars (Bhan et al., 1973; Mayaki et al., 1976; Jordan et al., 1979). Deeper roots or increased RLD must result in greater water extraction by the crop during the periods of water stress to give yield advantages over the drought susceptible genotypes. Increased RLD at depth and lower values of LL also enhanced water use efficiency (yield/evapotranspiration) of the crop because most of the additional water uptake from the subsoil was lost as transpiration. Thus, the approach used in the model to simulate the benefits of drought tolerance is appropriate.

While drought is the major yield-reducing factor under current climate, temperature increases with climate change will reduce yields at all four target sites studied. Incorporating heat tolerance in the sorghum virtual cultivars under climate change increased yields by $8-12 \%$ at Akola, followed by Cinzana (up to $9 \%$ ), Samanko (up to7\%) and Indore (up to 3\%). As the Indore site currently has high rainfall and moderate temperatures during the growing season, incorporating heat tolerance trait will not significantly benefit the crop in the near future. Heat tolerance exists among sorghum genotypes (Nguyen et al., 2013), thus it will be possible to breed sorghum cultivars for higher yield for the future climate conditions of the sites considered in this study. The yield gains due to heat tolerance simulated in this study are also realistic as the mechanisms that cause yield losses due to high temperature stress in the sorghum model are similar to those reported by Prasad et al. (2006, 2008). Mean air temperatures in these studies were lower than the threshold value for photosynthesis $\left(40^{\circ} \mathrm{C}\right)$ as used in the model, and therefore had no effect on photosynthesis and total biomass. On the other hand, temperatures at some sites were higher than the threshold value for grain-filling rate $\left(27^{\circ} \mathrm{C}\right)$ and affected seed-set and seed-size by influencing the seed-filling rate (Prasad et al., 2006, 2008). However more research is needed under field conditions to explore the effect of high temperatures on plant processes affecting crop yields when imposed at various stages of plant growth and development.

When various plant traits were considered in combinations, the resulting yield outcome frequently depended on environment (region, soils, present and future climate). Longer cycle cultivars were generally highest in yield, but not necessarily to a similar extent in all environments. Yield-enhancing traits generally increased yield, but their extent of yield increase was greater in short cycle cultivars, showing a trend toward interaction with cultivar life cycle. Likewise, drought tolerance traits were more beneficial in some regions and future climates, with less yield benefit in higher rainfall regions or higher rainfall future climates. Similarly, the heat tolerance trait had no benefit in one region, and it gave greater yield increase under future climates because of warmer temperature. So, the extent of additivity versus interaction of traits is dependent on environment as shown by Boote (2011). In addition, the sorghum model does not consider the impact of pests and diseases on crop growth and yield, which are expected to become more virulent under climate change.

The simulation study investigated the role of genetic improvement of sorghum for adapting to climate change in future. However, because the climate changes are projected to be small in the nearfuture, short-term agronomic adjustments could be more useful than genetic options for adapting to climate change and substantial benefits have been reported (Easterling, 1996; Howden et al., 2007). The agronomic practices may include changing the sowing date, fertilizer management, water conservation and efficient irrigation systems, integrated pest management, growing greater diversity of cultivars and the combination of these practices. As climate change becomes more severe a combination of both improved agronomic and genetic options will be needed for adapting to climate change. At every stage of adaptation process the prioritization of both agronomic and genetic improvement practices, in terms of yield or economic advantage, will be needed for adoption by the farmers under climate change.

\section{Conclusions}

Under both current and future climates, longer crop cycle duration and yield-potential traits increased sorghum yields to varying degrees at the target sites in India and Mali. Under current climate, the yield gains were larger by increasing drought tolerance than by increasing heat tolerance at the Akola, Indore and Cinzana sites and negligible at the Samanko site. Under climate change, the relative contribution of heat tolerance to yield gain increased at Akola (up to 12\%), Cinzana (up to 9\%), Samanko (up to 7\%) and marginal increase at Indore. The study reveals that under climate change different combinations of plant traits will be needed to increase and sustain yields of sorghum at the target sites. The CSM-CERES-Sorghum model and the virtual crop modeling approach used in this study can be useful to quantify yield benefits from incorporating individual or combination of traits to cope with climate change. However, the model findings of the study need to be field tested before adoption by plant breeders and farmers. In addition, this study used the output of only one GCM model and only one crop model. Future work is needed to quantify uncertainties in the simulation results associated with different approaches for modeling for heat and drought tolerance as simulated with multiple crop models and also related to climate change projections of many different GCM scenarios. 


\section{Acknowledgements}

This work was supported in part by the CGIAR Research Program on Policies, Institutions and Markets, The Global Futures Project funded by the Bill and Melinda Gates Foundation, the CGIAR Research Program on Climate Change, Agricultural and Food Security (CCAFS) and Dryland Cereals.

\section{Appendix A.}

In the CSM-CERES-Sorghum model, increased $\mathrm{CO}_{2}$ concentration in the atmosphere affects crop growth and yield through its effects on radiation use efficiency (RUE) and plant transpiration. These processes are simulated by the model as follows.

\section{A.1. $\mathrm{CO}_{2}$ effect on $\mathrm{RUE}$}

The model uses a two-variable $\left(X_{\mathrm{CO}_{2}}\right.$ and $\left.Y_{\mathrm{CO}_{2}}\right)$ lookup function that describes the relative effect of increased $\mathrm{CO}_{2}$ on daily dry matter accumulation rate that is normalized around $330 \mathrm{ppm}$ $\mathrm{CO}_{2}$ concentration, and is a multiplier of the RUE used to estimate biomass production (Table A.1). These functions were developed based on literature-reported $\mathrm{CO}_{2}$ response data of sorghum and maize listed in the USDA-ARS SAP4.3 report (Hatfield et al., 2008) and as presented by Boote et al. (2010).

\section{A.2. $\mathrm{CO}_{2}$ effect on transpiration}

Increased $\mathrm{CO}_{2}$ concentration in the atmosphere causes partial stomata closure, therefore, reduces the loss of water from the crop as transpiration. In the model a transpiration ratio (T-ratio) is calculated, which is the ratio of transpiration at a given level of $\mathrm{CO}_{2}$ concentration to the transpiration at $330 \mathrm{ppm}$ reference $\mathrm{CO}_{2}$ concentration. This is described by the following equation (Boote et al., 2010):

T-ratio $=\frac{\delta+\gamma \times\left(1.0+R_{\mathrm{c}} / R_{\mathrm{a}}\right)}{\delta+\gamma \times\left(1.0+R_{\mathrm{c}}^{\prime} / R_{\mathrm{a}}\right)}$

where $\delta$ represents the slope of the saturation vapor pressure-temperature relationship, $\gamma$ is the psychrometric constant, $R_{\mathrm{C}}$ is canopy resistance at a given level of $\mathrm{CO}_{2}$ concentration, $R_{\mathrm{c}}^{\prime}$ is canopy resistance at reference $\mathrm{CO}_{2}$ concentration and $R_{\mathrm{a}}$ is boundary layer resistance. $R_{\mathrm{C}}$ and $R_{\mathrm{C}}^{\prime}$ are computed as:

$R_{\mathrm{C}}=R_{\mathrm{LFC}} / \mathrm{LAI}$ and $R_{\mathrm{C}}^{\prime}=R_{\mathrm{LF}} / \mathrm{LAI}$, where $R_{\mathrm{LFC}}$ and $R_{\mathrm{LF}}$ are leaf resistances at the projected and reference levels of $\mathrm{CO}_{2}$ concentration, respectively, and LAI is leaf area index. $R_{\mathrm{LFC}}$ and $R_{\mathrm{LF}}$ are calculated as the sum of stomatal resistance and leaf boundary resistance assumed to be $10 \mathrm{~s} / \mathrm{m}$.

$R_{\mathrm{LFC}}=\left\{\frac{1}{0.0328-5.49 \times 10^{-5} \times \mathrm{CO}_{2}+2.96 \times 10^{-8} \times \mathrm{CO}_{2}^{2}}\right\}+10$

$R_{\mathrm{LF}}=\left\{\frac{1}{0.0328-5.49 \times 10^{-5} \times 330+2.96 \times 10^{-8} \times 330^{2}}\right\}+10$

In the CSM-CERES-Sorghum model, the T-ratio is used to adjust potential transpiration (EPo) only after daily reference evapotranspiration (ETo) is partitioned into potential soil evaporation (ESo)

Table A.1

Multiplier of RUE $\left(Y_{\mathrm{CO}_{2}}\right)$ for various levels of atmospheric $\mathrm{CO}_{2}$ concentration $\left(\mathrm{X}_{\mathrm{CO}_{2}}\right)$.

\begin{tabular}{lllllllllll}
\hline \multicolumn{1}{c}{$X_{\mathrm{CO}_{2}}(\mathrm{ppm})$} \\
\hline & 0 & 220 & 280 & 330 & 400 & 490 & 570 & 750 & 990 & 9999 \\
$Y_{\mathrm{CO}_{2}}$ & 0 & 0.85 & 0.95 & 1.00 & 1.02 & 1.04 & 1.05 & 1.06 & 10.7 & 1.08 \\
\hline
\end{tabular}

Table B.1

Relative response of photosynthesis (PCARB) and grain-filling rates (RGFIL) to temperature for the susceptible and tolerant cultivars as compared to the original values used in the model.

\begin{tabular}{|c|c|c|c|c|}
\hline & \multicolumn{4}{|c|}{ Temperature thresholds $\left({ }^{\circ} \mathrm{C}\right)$} \\
\hline & Tbase & Topt1 & Topt2 & Tmax \\
\hline \multicolumn{5}{|l|}{ PCARB } \\
\hline Original values & 8.0 & 20.0 & 40.0 & 50.0 \\
\hline $\begin{array}{l}\text { Adjusted values } \\
\text { (susceptible and } \\
\text { tolerant cultivars) }\end{array}$ & 8.0 & 20.0 & 40.0 & 44.0 \\
\hline $\begin{array}{l}\text { Relative response } \\
\quad \text { (unitless) }\end{array}$ & 0.0 & 1.0 & 1.0 & 0.0 \\
\hline \multicolumn{5}{|l|}{ RGFIL } \\
\hline Original values & 7.0 & 22.0 & 48.0 & 50.0 \\
\hline $\begin{array}{l}\text { Adjusted values } \\
\text { (susceptible cultivar) }\end{array}$ & 7.0 & 22.0 & $27.0^{\mathrm{a}}$ & $35.0^{\mathrm{a}}$ \\
\hline $\begin{array}{l}\text { Adjusted values } \\
\text { (tolerant cultivar) }\end{array}$ & 7.0 & 22.0 & 29.0 & 37.0 \\
\hline $\begin{array}{l}\text { Relative response } \\
\quad \text { (unitless) }\end{array}$ & 0.0 & 1.0 & 1.0 & 0.0 \\
\hline
\end{tabular}

Tbase, base temperature; Topt1, lower optimum temperature; Topt2, upper optimum temperature; Tmax, damaging "failure" temperature.

a Threshold temperatures for grain-filling rate are based on Prasad et al. (2006).

and EPo. As a result, the actual evapotranspiration (EP) will be lower at higher $\mathrm{CO}_{2}$ levels relative to the computation at $330 \mathrm{ppm}$. Also, in the CSM model the $R_{\mathrm{a}}$, which varies daily during the season, is based on plant height, LAI and wind speed at $2 \mathrm{~m}$ height.

\section{Appendix B.}

The effects of temperature on photosynthesis and grain-filling rates were revised for the susceptible and heat tolerant cultivars of sorghum. These changed values in the model are presented in Table B.1. Current DSSAT V4.6 release uses the revised values, assuming susceptible cultivars.

\section{Appendix C.}

Table C.1.

\section{Table C.1}

Genetic coefficients of the three sorghum baseline cultivars used in the study.

\begin{tabular}{lccc}
\hline Genetic coefficient & \multicolumn{2}{c}{ Cultivars } & \\
\cline { 2 - 4 } & CSV 15 & CSM 335 & CSM 63E \\
\hline P1 & 400.0 & 413.0 & 300.0 \\
P2 & 102.0 & 102.0 & 102.0 \\
P2O & 12.8 & 12.8 & 12.6 \\
P2R & 120.0 & 280.0 & 80.0 \\
PANTH & 617.5 & 617.5 & 547 \\
P3 & 152.5 & 152.5 & 142.5 \\
P4 & 81.5 & 81.5 & 61.5 \\
P5 & 640.0 & 640.0 & 350 \\
PHINT & 49.0 & 49.0 & 49.0 \\
G1 & 7.0 & 3.0 & 15.0 \\
G2 & 6.2 & 4.0 & 5.5
\end{tabular}

$\mathrm{P} 1$, thermal time from seedling emergence to the end of the juvenile phase (degree days); P2, thermal time from the end of the juvenile stage to tassel initiation under short days (degree days); P2O, critical photoperiod or the longest day length (in h) at which development occurs at a maximum rate. At values higher than $\mathrm{P} 2 \mathrm{O}$, the rate of development is reduced; P2R, extent to which phasic development leading to panicle initiation (expressed in degree days) is delayed for each hour increase in photoperiod above P2O; PANTH, thermal time from the end of tassel initiation to anthesis (degree days); P3, thermal time from end of flag leaf expansion to anthesis (degree days); P4, thermal time from anthesis to beginning grain filling (degree days); P5, thermal time from beginning of grain filling to physiological maturity (degree days); PHINT, phylochron interval; the interval in thermal time between successive leaf tip appearances (degree days); G1, scalar for relative leaf size; G2, scalar for partitioning of assimilates to the panicle (head). 


\section{References}

AICRPS, 1994-2008. Annual Reports, All India Coordinated Research Project on Sorghum. National Research Centre for Sorghum, Rajendra Nagar, Hyderabad, Indian Council of Agricultural research, New Delhi.

Alagarswamy, G., Ritchie, J.T., 1991. Phasic development in CERES-Sorghum model. In: Hodges, T. (Ed.), Predicting Crop Phenology. CRC Press, Boca Raton, FL, pp. $143-152$.

Bhan, S., Singh, H.G., Singh, A., 1973. Note on root development as an index of drought resistance in sorghum (Sorghum bicolor L. Moench). Indian J. Agric. Sci. $43,828-830$.

Blane, E., 2012. The impact of climate change on crop yields in Sub-Saharan Africa. Am. J. Climate Change 1,1-13.

Boote, K.J., 2011. Improving soybean cultivars for adaptation to climate change and climate variability. In: Yadav, S.S., Redden, R.J., Hatfield, J.L., Lotze-Campen, H., Hall, A.E. (Eds.), Crop Adaptation to Climate Change. Wiley-Blackwell, West Sussex, UK, pp. 370-395.

Boote, K.J., Allen Jr., L.H., Vara Prasad, P.V., Jones, J.W., 2010. Testing effects of climate change in crop models. In: Hillel, D., Rosenzweig, C. (Eds.), Handbook of Climate Change and Agroecosystems. Imperial College Press, London, pp. 109-129.

Boote, K.J., Ibrahim, A.M.H., Lafitte, R., McCulley, R., Messina, C., Murray, S.C., Specht, J.E., Taylor, S., Westgate, M.E., Glasener, K., Bijl, C.G., Giese, J.H., 2011. Position statement on crop adaptation to climate change. Crop Sci. 51, 2337-2343.

Boote, K.J., Tollenaar, M., 1994. Modeling genetic yield potential. In: Boote, K.J., Bennett, J.M., Sinclair, T.R., Paulsen, G.M. (Eds.), Physiology and Determination of Crop Yield. ASA-CSSA-SSSA, Madison, WI, pp. 533-565.

Boote, K.J., Kropff, M.J., Bindraban, P.S., 2001. Physiology and modelling of traits in crop plants: implications for genetic improvement. Agric. Syst. 70, 395-420.

Bristow, R.L., Campbell, G.S., 1984. On the relationship between incoming solar radiation and daily maximum and minimum temperature. Agric. Forest Meteorol. 31, 159-166.

Butt, T.A., McCarl, B.A., Angerer, J., Dyke, P.T., Stuth,J.W., 2005. The economic and food security implications of climate change in Mali. Climate Change 68, 355-378.

Chipanshi, A.C., Chanda, R., Totolo, O., 2003. Vulnerability assessment of the maize and sorghum crops to climate change in Botswana. Climate Change 61, 339-360.

Cooper, P., Rao, K.P.C., Singh, P., Dimes, J., Traore, P.S., Rao, K., Dixit, P., Twomlow, S., 2009. Farming with current and future climate risk: advancing a 'hypothesis of hope' for rain-fed agriculture in the semi-arid tropics. J. SAT Agric. Res. 7, 1-19.

Easterling, W.E., 1996. Adapting North American agriculture to climate change in review. Agric. Forest Meteorol. 80, 1-53.

FAO, 2012. Food and Agriculture Organization of the United Nations, www://faostat.fao.org/ (accessed 15.01.13).

Fischer, G., Shah, M., Tubiello, F.N., Van Velhuizen, H., 2005. Socio-economic and climate change impacts on agriculture: an integrated assessment, 1990-2080. Philos. Trans. Roy. Soc. B 360, 2067-2073.

Hammer, G.L., Butler, D.G., Muchow, R.C., Meinke, H., 1996. Integrating physiological understanding and plant breeding via crop modeling and optimization. In: Cooper, M., Hammer, G.L. (Eds.), Plant Adaptation and Crop Improvement. CAB International, Wallingford, pp. 419-441.

Hammer, G.L., Carberry, P.S., Muchow, R.C., 1993. Modelling genotypic and environmental control of leaf area dynamics in grain sorghum. I. Whole plant level. Field Crops Res. 33, 293-310.

Hammer, G.L., Chapman, S., Van Oosterom, E., Podlich, D., 2005. Trait physiology and crop modeling as a framework to link phenotypic complexity to underlying genetic systems. Aust. J. Agric. Res. 56, 947-960.

Hammer, G.L., Kropff, M.J., Sinclair, T.R., Porter, J.R., 2002. Future contributions of crop modeling: from heuristics and supporting decision making to understanding genetic regulation and aiding crop improvement. Eur. J. Agron. 18, 15-31.

Hammer, G.L., Van Oosterom, E., McLean, G., Chapman, S.C., Broad, I., Harland, P., Muchow, R.C., 2010. Adapting APSIM to model the physiology and genetics of complex adaptive traits in field crops. J. Exp. Bot 61, 2185-2202.

Hatfield, J., Boote, K.J., Fay, P., Hahn, L., Izaurralde, C., Kimball, B.A., Mader, T., Morgan, J., Ort, D., Polley, W., Thomson, A., Wolfe, D., 2008. Agriculture. In: The Effects of Climate Change on Agriculture, Land Resources, Water Resources, and Biodiversity in the United States., pp. 362, A Report by the U.S. Climate Change Science Program and the Subcommittee on Global Change Research. Washington, DC, USA.

Hoogenboom, G., Jones, J.W., Wilkens, P.W., Porter, C.H., Boote, K.J., Hunt, L.A., Singh, U., Lizaso, J.L., White, J.W., Uryasev, O., Royce, F.S., Ogoshi, R., Gijsman, A.J., Tsuji, G.Y., 2010. Decision Support System for Agrotechnology Transfer (DSSAT) Version 4.5 [CD-ROM]. University of Hawaii, Honolulu, Hawaii.

Howden, S.M., Soussana, J.F., Tubiello, F.N., Chhetri, N., Dunlop, M., Meinke, H., 2007. Adapting agriculture to climate change. Proc. Natl. Acad. Sci. U. S. A. 104, 19691-19696.

IPCC, 2001. Climate Change 2001: The Scientific Basis. Contribution of Working Group I to the Third Assessment Report of the Intergovernmental Panel on Climate Change. Cambridge University Press, Cambridge, UK, pp. 881.
IPCC, 2007. Climate Change 2007. The Physical Science Basis, Contribution of Working Group I to the Fourth Assessment Report of the Intergovernmental Panel on Climate Change. Cambridge University Press, Cambridge, UK, pp. 996.

Jones, J.W., Hoogenboom, G., Porter, C.H., Boote, K.J., Batchelor, W.D., Hunt, L.A. Wilkens, P.W., Singh, U., Gijsman, A.J., Ritchie, J.T., 2003. DSSAT cropping system model. Eur. J. Agron. 18, 235-265.

Jordan, W.R., Dugas Jr., W.A., Shouse, P.J., 1983. Strategies for crop improvement for drought-prone regions. Agric. Water Manage. 7, 281-289.

Jordan, W.R., Miller, F.R., Morns, D.E., 1979. Genetic variation in root and shoot growth of sorghum in hydroponics. Crop Sci. 19, 468-472.

Lafolie, F., Bruckier, L., Tardieu, F., 1991. Modeling root water potential and soil-root water transport 1. Model presentation. Soil Sci. Soc. Am. J. 55, 1203-1212.

Lal, S., Deshpande, S.B., Sehgal, J., 1994. Soil Series of India. Soils Bulletin 40. National Bureau of Soil Survey and Land Use Planning, Nagpur, India, pp. 648.

Landivar, J.A., Baker, D.N., Jenkins, J.N., 1983. Application of GOSSYM to genetic feasibility studies, II. Analyses of increasing photosynthesis, specific leaf weight and longevity of leaves in cotton. Crop Sci. 23, 504-510.

Mayaki, W.C., Stone, L.R., Teare, I.D., 1976. Irrigated and non-irrigated soybean, corn and grain sorghum root systems. Agron. J. 68, 532-534.

Narayanan, S., Aiken, R.M., Prasad, P.V.V., Xin, Z., Yu, J., 2013. Water and radiation use efficiencies in sorghum. Agron. J. 105 (3), 649-659.

Nguyen, C.T., Singh, V., Van Oosterom, E.J., Chapman, S.C., Jordan, D.R., Hammer, G.L., 2013. Genetic variability in high temperature effects on seed-set in sorghum. Funct. Plant Biol., http://dx.doi.org/10.1071/FP12264.

Messina, C.D., Jones, J.W., Boote, K.J., Vallejos, C.E., 2006. A gene-based model to simulate soybean development and yield responses to environment. Crop Sci. $46,456-466$

Passioura, J.B., 1983. Root and drought resistance. Agric. Water Manage. 7, 265-280.

Payne, R.W., Harding, S.A., Murray, D.A., Soutar, D.M., Baird, D.B., Glaser, A.I., Channing, I.C., Welham, S.J., Gilmour, A.R., Thompson, R., Webster, R., 2009. The Guide to GenStat Release 12, Part 2: Statistics. VSN International, Hemel Hempstead, pp. 256.

Prasad, P.V.V., Boote, K.J., Allen Jr., L.H., 2006. Adverse high temperature effects on pollen viability, seed-set, seed yield and harvest index of grain-sorghum [Sorghum bicolor (L.) Moench] are more severe at elevated carbon dioxide due to high tissue temperature. Agric. Forest Meterol. 139, 237-251.

Prasad, P.V.V., Pisipati, S.R., Mutava, R.N., Tuinstra, M.R., 2008. Sensitivity of grain sorghum to high temperature stress during reproductive development. Crop Sci. 48, 1911-1917.

Reddy, B.V.S., Ashok Kumar, A., Sampangiramireddy, R., Reddy, P.S., 2011. Sorghum genetic enhancement for climate change adaptation. In: Yadav, S.S., Redden, R., Hatfield, J.L., Lotze-Campen, H., Hall, A.E. (Eds.), Crop Adaptation to Climate Change. Wiley-Blackwell, UK, pp. 326-339.

Reddy, V.G., Upadhyaya, H.D., Gowda, C.L., 2006. Current status of sorghum genetic resources at ICRISAT: their sharing and impacts. Int. Sorghum Millets Newslett. 47, 9-13.

Ritchie, J.T., Singh, U., Godwin, D.C., Bowen, W.T., 1998. Cereal growth, development and yield. In: Tsuji, G.Y., Hoogenboom, G., Thornton, P.K. (Eds.), Understanding Options for Agricultural Production. Kluwer Academic Publishers, Dordrecht, The Netherlands, pp. 79-98.

Ritchie, J.T., 1998. Soil water balance and plant stress. In: Tsuji, G.Y., Hoogenboom, G., Thornton, P.K. (Eds.), Understanding Options for Agricultural Production. Kluwer Academic Publishers, Dordrecht, The Netherlands, pp. 41-54.

Singh, P., Boote, K.J., Kumar, U., Srinivas, K., Nigam, S.N., Jones, J.W., 2012. Evaluation of genetic traits for improving productivity and adaptation of groundnut to climate change in India. J. Agron. Crop Sci. 198, 399-413.

Srivastava, A., Kumar, S.N., Aggarwal, P.K., 2010. Assessment on vulnerability of sorghum to climate change in India. Agric. Ecosyst. Environ. 138 160-169.

Suriharn, B., Patanothai, A., Boote, K.J., Hoogenboom, G., 2011. Designing a peanut ideotype for a target environment using the CSM-CROPGRO-Peanut model. Crop Sci. 51, 1887-1902.

Tardieu, F., 2003. Virtual plants: modelling as a tool for genomics of tolerance to water deficit. Trends Plant Sci. 8, 9-14.

Tingem, M., Ravington, M., Bellocchi, G., 2009. Adaptation assessment for crop production in response to climate change in Cameroon. Agron. Sust. Dev. 29, 247-256.

Tingem, M., Ravington, M., Bellocchi, G., Azam-Ali, S., Collis, J., 2008. Effect of climate change on crop production in Cameroon. Climate Res. 36, 65-77.

White, J.W., Hoogenboom, G., 2003. Gene-based approaches to crop simulation: past experiences and future opportunities. Agron. J. 95, 52-64.

Willmott, C.J., 1982. Some comments on the evaluation of model performance. Bull. Am. Meteorol. Soc. 63, 1309-1313.

Yin, X., Kropff, M.J., Stam, P., 1999. The role of ecophysiological models in QTL analysis: the example of specific leaf area in barley. Heredity 82, 415-421. 